\title{
Dermal benefits of topical D-ribose
}

This article was published in the following Dove Press journal:

Clinical, Cosmetic and Investigational Dermatology

8 September 2009

Number of times this article has been viewed

\author{
Linda M Shecterle \\ John A St. Cyr \\ Jacqmar, Inc., Minneapolis, MN, USA
}

Correspondence: Linda M Shecterle Jacqmar, Inc., 10965 53rd Avenue North, Minneapolis, MN 55442, USA

Tel +l 7634733007

Fax +I 7633835155

Email Ims94@aol.com
Abstract: Our aging skin undergoes changes with reductions in collagenous and elastic fibers, fibroblasts, mast cells, and macrophages with free radical production, which can result in reduced skin tone and wrinkle formation. Fibroblasts are important for dermal integrity and function with a decrease in function producing less skin tone, thinning, and wrinkle formation. Dermal levels of adenosine triphosphate (ATP) decline with aging, potentially altering dermal function. Supplemental D-ribose, a natural occurring carbohydrate, enhances ATP regeneration. D-ribosebased studies demonstrated benefits in both cell culture fibroblastic activities and a subsequent clinical study in women with decreased skin tone with wrinkles. Supplemental D-ribose may offer this needed cellular benefit.

Keywords: dermal, fibroblast, ATP, aging, wrinkles

As we age our skin undergoes changes with reductions in collagenous and elastic fibers, fibroblasts, mast cells, macrophages, and a constant interaction with reactive oxygen species, which clinically can be manifested by a loss in elasticity and the production of wrinkles. ${ }^{1-3}$ Fibroblasts are important for the maintenance of dermal integrity and function and decreased function can clinically result in less skin tone, thinning of the skin, and the formation of wrinkles.

Dermal cellular adenosine triphosphate (ATP) levels decline with aging. Muggleton-Harris and DeFuria reported a change in the cellular ATP content in fibroblasts and abnormal ATP turnover with aging, creating an energy deficiency, which can potentially alter dermal function. ${ }^{4}$ Energy supplementation continues to attract interest. D-ribose, a natural occurring pentose carbohydrate, regenerates ATP levels with improving cellular function following stress, in preserved blood cells, a role in oxidative stress, and more recently in cultured fibroblasts..$^{5-8}$ Borel and colleagues reported an enhancement in both mitochondrial and cytosolic respiration rates, important markers of fibroblastic activity, with D-ribose in cultured human fibroblasts. ${ }^{8}$ D-ribose $(0.05 \%)$ significantly stimulated both mitochondrial and cytosolic oxygen consumption respiratory rates (37\% and $31 \%$, respectively; $P<0.05$ ). Furthermore, measured ATP levels revealed a $19 \%$ elevation with D-ribose ( $0.05 \%)$ during hypoxia and no benefit in normal oxygenated conditions.

Besides these positive in vitro findings, D-ribose has also demonstrated clinical benefits. A topical D-ribose-based (0.5\%) facial lotion was tested in adult women with decreased skin tone and wrinkles. Twenty adult females were evaluated both 
objectively and subjectively at 14 and 28 days while daily applying this D-ribose-based cosmetic lotion. After 14 days, there was a significant reduction $(12.2 \%)$ in total wrinkle surface area and a demonstrable (9.1\%) reduction in total wrinkle length. Further cosmetic benefits were observed at 28 days though the reduction in total wrinkle surface area of $12.2 \%$ remained the same with a further reduction in average wrinkle length to $17.6 \%$. Subjectively, $67 \%$ of the adults perceived their skin to be more radiant and glowing with $71 \%$ noticing less skin dullness. ${ }^{9}$ Of note, the Maillard browning reaction occurs between reducing sugars, such as ribose, and amines, causing a browning situation, which may promote self-tanning, another potential added feature for the use of ribose. ${ }^{10}$ These preliminary studies demonstrated the potential benefits of D-ribose, both in cultured fibroblasts and the described clinical study. The clinical benefits may have the potential to produce a more youthful, radiant, and healthy appearance of the skin.

\section{Disclosures}

The authors report no conflicts of interest in this work.

\section{References}

1. Mantagna W, Carlisle L. Structural changes in aging skin. $\mathrm{Br} J$ Dermatol. 1990;122(Suppl 35):61-70.

2. Roupe G. Skin of the aging human being. Lakartidningen. 2001; 98(10):1091-1095.

3. Emerit I. Free radicals and aging of the skin. EXS. 1992;62:328-341.

4. Muggleton-Harris AL, Defuria R. Age-dependent metabolic changes in cultured human fibroblasts. In Vitro Cell Dev Biol. 1985;21: 271-276.

5. Schneider JR, St. Cyr JA, Mahoney JR, Bianco RW, Ring WS, Foker JE. Recovery of ATP and return of function after global ischemia. Circ (Part II). 1985;72(4):II-298.

6. Karnicki K, Johnson C, St. Cyr J, Ericson D, Rao G. Platelet storage solution improves the in vitro function of preserved platelet concentrate. Vox Sang. 2003;85(4):262-266.

7. Seifert JG, Subudi AW, Fu MX, et al. The role of ribose on oxidative stress during hypoxic exercise: a pilot study. $J$ Med Food. 2009;12:690-693.

8. Borel M, Calmon E, Bezivin C, Pletsch S, St. Cyr J. D-ribose enhances basal and mitochrondrial respiratory rates in human dermal fibroblasts FASEB J. 2007;21(6):A835.

9. Patent Application \#20070231288; Arnaud, Jean-Pierre et al; Cosmetic Use Of D-Ribose And Method Thereof.

10. Bailey AJ, Sims TJ, Avery NC, Halligan EP. Non-enzymatic glycation of fibrous collagen: reaction products of glucose and ribose. Biochem $J$. 1995;305(Pt2):385-390.
Clinical, Cosmetic and Investigational Dermatology

\section{Publish your work in this journal}

Clinical, Cosmetic and Investigational Dermatology is an international, peer-reviewed, open access, online journal that focuses on the latest clinical and experimental research in all aspects of skin disease and cosmetic interventions. All areas of dermatology will be covered; contributions will be welcomed from all clinicians and

\section{Dovepress}

basic science researchers globally. This journal is indexed on CAS. The manuscript management system is completely online and includes a very quick and fair peer-review system, which is all easy to use. Visit http://www.dovepress.com/testimonials.php to read real quotes from published authors. 